\title{
THE COSMOPOLITAN AND ENVIRONMENTAL CHALLENGES OF THE IDEA OF EUROPE IN THE AGE OF THE ANTROPOCENE
}

\author{
OS DESAFIOS COSMOPOLITAS E AMBIENTAIS DA IDEIA DE \\ EUROPA NA ERA DO ANTROPOCENO
}

\author{
Bruno Rego* \\ labirintosdialogicos@yahoo.com
}

\begin{abstract}
In this paper we try to show how the contemporary challenges of the global environmental crisis in the age of the Anthropocene confront us with the urgent need of reevaluating the premises of classical contractualism and designing a new idea of Europe for the 21st century. We begin by expounding the principles of what we call an enviro-social contract which takes the environmental crisis as the main axis of our ontological condition in the contemporary world to subsequently identifying in the remaining sections the main theoretical issues on the possibility of a new environmental and cosmopolitan idea of cosmopolitan Europe according to our previous arguments. We finish by proposing cities as cosmopolitan political agents which can contribute to rethink the idea of Europe through the creation of a cosmopolitan political culture in face of the current European sociopolitical and institutional crossroads.
\end{abstract}

Keywords: Anthropocene; Environment; Europe; Cosmopolitanism; Cities.

Sumário. Neste artigo, tentamos mostrar como os desafios contemporâneos da crise ambiental global na era do Antropoceno nos confrontam com a necessidade urgente de reavaliação dos princípios do contratualismo clássico e de projetar uma nova ideia de Europa para o século XXI. Começamos por enfocar os princípios do que chamamos de contrato ambisocial, que considera a crise ambiental como o eixo principal de nossa condição ontológica no mundo contemporâneo, para posteriormente identificar nas seções restantes as principais questões teóricas em torno da possibilidade de uma nova ideia ambiental e cosmopolita de Europa em consonância com os nossos argumentos anteriores. Terminamos propondo as cidades como agentes políticos cosmopolitas que podem contribuir para repensar a ideia de Europa através da criação de uma cultura política cosmopolita frente às atuais encruzilhadas sociopolíticas e institucionais europeias.

Palavras-chave: Antropoceno; Ambiente; Europa; Cosmopolitismo; Cidades.

\footnotetext{
${ }^{*}$ Universidade de Lisboa, Centro de Estudos Comparatistas (colaborador) e Universidade do Minho, Centro de Ética, Política e Sociedade (colaborador).
} 


\section{o. On Environmental Citizenship as the Axis of an Enviro-Social Contract}

If we wish to start to identify the $21^{\text {st }}$ century's most complex problems, then we must clearly bear in mind a word that became part of our daily lives: environment. The severe, and many times frightening, possible implications of the current environmental crisis in the present and the future of our planet brought new, vast and unprecedented global challenges not only to sociopolitical arenas, but to contemporary political philosophy as well.

Given the predominance of environmental issues in the national and international political agendas, one of contemporary political philosophy's greatest tasks is certainly to research a new conceptual framework that takes into account the relationship between citizenship and environment. Or in other words: to find a balance between the vindication of environmental rights and the idea of collective responsibility.

In spite of being a discipline only with three decades of existence, it is possible to distinguish two different types of intellectual contributions to this subject.

Following the framework established by the British sociologist T.H. Marshall in his seminal and classic paper, "Citizenship and Social Class", some authors focus more on rights than on duties concerning a concept of environmental citizenship. Contrarily others distance themselves from Marshall's framework and try to pursue an ecological notion of citizenship which emphasizes heavily the sphere of ecological obligations and responsibilities to future generations, and in some cases even to non-human forms of life in a sort of holistic ecological republicanism.

Notwithstanding the merit of these early attempts, however we owe to the British political scientist, Andrew Dobson, the most detailed and original account of an ecological citizenship notion in works such as his paper "Ecological Citizenship: A Disruptive Influence" or the full length book Citizenship and the Environment in which he displays more accurately his arguments on the subject. 
Somehow ignoring the complex challenges brought at many levels by the global environmental crisis to this century, Dobson's notion of ecological citizenship can be reduced primarily to a materialistic narrative of production, consumption and exchange of natural resources, focusing its approach mostly on duties or communities of obligation in a non-reciprocal flow between the developed Northern hemisphere and the emerging Southern hemisphere of the globe.

In face of the complexity of issues involved in the global environmental crisis, Dobson's notion of ecological citizenship is an excessively reductionist perspective to address the problem mainly because of the narrowness of his arguments regarding key aspects of the relationship between citizenship and the environment:

1) Dobson's emphasis on ecological duties and on the private sphere seems to ignore or at least to undervalue the inherent dialectics in the dynamics of citizenship, that is, the relationship between the individual and the state. Given the role of political institutions in the resolution of environmental issues, an approach on rights must be also a feature of an environmental/ecological citizenship notion;

2) Dobson's absence of a point of view on the techno-scientific paradigm and on the idea of progress. A theoretical framework on citizenship regarding environmental issues must hold a critical position on the role of science and its social implications, and also on new techno-scientific schools such as Transhumanism or Singularity which propose to transcend the human condition into a post-human future.

To build a notion of environmental citizenship beyond an ecocentric approach and beyond Dobson's notion as well, we must bear in mind that the global environmental crisis represents a unique historical moment in which nature is an unsurpassable actor in the history of human civilization. But more than that, it is also a unique opportunity to expand the premises of social contract theory.

The global environmental crisis marks the passage of a fictional state of nature as a pre-condition of social contract theories to the real state of the 
nature, that is, the planetary ecosystems disrupted by anthropogenic activities, as a necessary condition to extend the scope of contractualism to unprecedented horizons of thinking.

A new approach to the contractualist theory takes the environment as the primal human existence's condition of possibility and of planetary ecological balance. In that sense it stops being a traditional social contract, expression of the legal and political relationships between the individual and the state, becoming thus an enviro-social contract in which environmental issues play a vital role for the planetary human and non-human forms of life.

The social contract's extension has crucial consequences regarding citizenship, mainly in terms of its environmental focus: it is no longer a matter of guaranteeing only the fundamental human rights but an imperative of engaging both political institutions and civil society in the challenges of the transition to sustainability.

It means also to widen the modern contractualist conceptual background by acknowledging that environmental issues forge a new set of social vindications and a balance between rights and collective responsibility:

1) Vindication of a democratic society based on principles of economic justice, social equity, environmental sustainability and cultural diversity that promotes the increasing of civil society participation opportunities in sustainability issues. That is, to rethink the nature and functioning of democratic political regimes;

2) Vindication of economic and techno-scientific paradigms that work in the boundaries of planetary sustainability. That is, to criticize and to reject paradigms of infinite technological and economic progress;

3) Responsibility for the preservation of life conditions of both future generations and non-human forms of life not from an ecocentric and unrealistic perspective but through the only possible realistic approach. It means to focus on environmental rights as an extension of human rights envisaged as duties towards future generations and the natural world through an enlightened, conscious and civically engaged anthropocentrism. 
Notwithstanding Dobson's excessive emphasis on ecological citizenship duties, environmental citizenship as an extension of the modern contractualist premises does not presuppose obviously an exclusive focus on rights. It proposes instead a balance between rights and duties because the vindications and responsibilities mentioned above require a committed civil society in the issues of our time.

Contrary to an ecocentric approach that, if pushed to radical limits, may become an authoritarian sociopolitical regime, this environmental citizenship notion can only be fully achieved as part of liberal democratic societies. But this is not all. In order to achieve the citizen's effective empowerment and engagement in environmental issues, the environmental citizenship notion we are building here must also be conceived through the lens of hope and utopia.

\section{On Sustainability and Utopia as an Anthropology of Hope}

Assuming that the transition to environmentally resilient societies is an impossible collective task without civil society's full commitment, we need an approach that transcends sustainability's narrow social, economic and environmental dimensions. First, it is necessary to endow sustainability with a sound cultural dimension which is seldom focused on the official speech of sociopolitical institutions. From an environmental citizenship's perspective, what is at stake is how to create a sustainable civic culture able to foster civil society's engagement and participation opportunities in environmental issues' decisionmaking processes.

Therefore, we must refuse Hans Jonas's political solution proposed in the Imperative of Responsibility. According to him only authoritarian sociopolitical regimes and the government of a good-minded and elitist tyranny are able to cope with the contemporary environmental challenges. Jonas's argument clearly leaves no room for civic engagement in sustainability issues. For the same reason, we must also decline the catastrophic scenarios with which are often portrayed the environmental prospects for the future, and whose message of doom may end in paralysis and fear. Aiming at an environmental citizenship's effective exercise, 
we need to focus on sustainability from the perspective of hope to assure civil society's commitment in the transition to a more sustainable world.

Avoiding an ingenuous faith in the future (as is common among most of the faithful supporters of technological progress), to envisage sustainability as an anthropology of hope from an environmental citizenship's outlook means to think of it not only under a framework of responsibility, but also as a possible contemporary mobilizing call that enables and stimulates civic action and commitment in future environmental challenges.

To achieve that, besides hope, we must also rescue sustainability from its common background and envisage it through the lens of utopia, widening thus its conceptual territory. It is not a matter of focus on sustainability as utopia in the sense of a fictional nowhere as Thomas More's Utopia, but of recovering utopian thinking's positive aspects neglected by contemporary political paradigms, and as identified by Paul Ricoeur:

1) To identify the political and social conditions of the established paradigm;

2) To express critical points of view against the established paradigm and to present alternative models to it. ${ }^{1}$

So what remains assigned to utopian thinking regarding sustainability from an environmental citizenship's outlook is:

1) The capacity of evaluating the dominant and unsustainable paradigms;

2) The exercise of its critical function in order to explore different social, economic and political alternatives that may contribute to new and sustainable sociopolitical models.

However, we still need to go further on this. We must also focus on sustainability as utopia from the perspective of Ernst Bloch's very peculiar reading of the concept in the Principle of Hope: utopia as a concrete possibility of designing new and alternative futures in an historical process whose chances remain fully open and non-yet entirely given. In the sense of a yet undetermined possibility, sustainability fits perfectly Bloch's notion of concrete utopia, that is, 
a dynamic and ongoing process of constructing alternative futures as a solution to our unsustainable present scenarios.

If there is any real possibility of an environmental citizenship's effective exercise and of turning sustainability into a mobilizing myth for collective action, that will not be possible without focusing more on hope than on fear in issues such as climate change's future impacts.

And it certainly will not be achievable without the presence of utopian thinking's critical tools in the design of long-term collective and sustainable futures. Though we may not be overoptimistic about the prospects for the next decades, we must at least save some room for hope and utopia in sustainability issues. Otherwise, we may be confronted with the social risk of losing our greatest civilizational challenge. So a constant reminder in these uncertain times must be: according to Ernst Bloch's understanding of utopia, the future is something notyet fully designed.

After establishing mutual affinities between citizenship, environment and sustainability, it is now time to bring the idea of Europe to the discussion. In order to give sequence to the previous arguments, the next two sections intend to raise some relevant issues on the idea of Europe's ongoing debate. The main question we will pursue is this: which sociopolitical agents will be able to foster an envirosocial contract as the one we have developed and to bring fresh approaches to a new cosmopolitan and environmental idea of Europe that is required in face of the Anthropocene challenges?

\section{On the idea of Europe: A New Social Contract or an Enviro- Social Contract?}

After sixty years of gradual sociopolitical conquests achieved against the first half of the $20^{\text {th }}$ century's barbarian violence, nowadays the idea of Europe is undeniably a disenchanted territory. Currently both the European Union and its political project, in the absence of a hopeful future beyond the framework of its institutional and civic paralysis, seem to have arrived to a dead end. They are both unable to cope with the greatest challenges of our century. 
It is precisely at this point that the future of the idea of Europe after the Second World War and the global environmental crisis collide. In our uncertain century marked by several unfortunate events, the environmental crisis represents not only a fruitful possibility for a new approach on modern contractualism premises. It is also a new step to rethink the idea of Europe from the core and to expand its theoretical framework in order to reach an effective European civil society.

In a recent essay, Ulrich Beck claims that we need a new European social contract in order to bring closer the European institutions and its citizens, and to recast the basic principles of the European integration project. ${ }^{2}$

But there is much more at stake than just sociopolitical issues. Seen through a wider angle, the current moment of crisis, that is both European and environmental, will impose on us a more radical task than Beck's aforementioned arguments. Our troubled century invites us to rethink the future of the idea of Europe and its cosmopolitan roots from the angle of the environmental challenges that confront us with the emergence of a new geological period, the Anthropocene.

We will not mention here the ongoing debates surrounding the construction and the validity of such controversial concept. But, according to the lines of that debate applied to an environmental and cosmopolitan idea of Europe, we claim that more than a social contract revision it is necessary to implement the premises of a European enviro-social contract based on sustainability, hope and on utopian thinking critical tools' as exposed in Section 2. Only by expanding the classical approach on this subject, will we be able to fully acknowledge the complexities of our contemporary sociopolitical reality, and to find alternative solutions to what Beck calls the last effective political utopia. This is one side of the problem.

The other side confronts us directly with the challenge of thinking the idea of Europe's cosmopolitanism from the scope of the global contemporary environmental impacts. This task brings necessarily some implications both to its past and future. In the first place, we need to break away with a certain idea of 
Europe that is part of the European identity mythology and that was completely ineffective in the creation of a real European civic culture.

The idea of Europe in terms of its past cannot be exclusively attached to a common cultural and spiritual heritage. It is an idea focused mostly on the cultural splendor of Western Europe as George Steiner, among others, claims. If we take a deep look into the complexity of European history, we find that the European common cultural heritage, the Republique des Belles Lettres, is a land that only anelite really inhabited and that seldom expressed a real cosmopolitan approach as the one now needed in contemporary Europe.

According to this argument we must ask: can this elitist idea of Europe foster a real European civil society? Can this common cultural heritage mythology socio-politically enchant a vast geographical space whose affinities were retrospectively built, and, as if this was not enough, is being shaken by the resurgence of anti-European nationalist and populist ghosts of a not so distant past?

The most remarkable challenge to the project of European integration above and beyond the selfish national interests of the various nations that compose the EU lies precisely in their history: the aforementioned elitist idea of Europe does not cope entirely with the rich national historiographies of twenty seven member states searching for a common cosmopolitan background.

A deep analysis of the roots of European history should teach us more about the true cosmopolitanism of the idea of Europe, more than perhaps many of those who share the elitist approach like to verbalize or even admit: there is not a single Europe, but a plethora of imaginaries and discourses within this intellectual territory.

In other words: to acknowledge the diversity of the European public space, and also to reshape bottom-up and in a cosmopolitan way the past of the idea of Europe, we need to have a larger focus on European history, in the sense of what was claimed by Tony Judt: there is not a single idea of Europe, but a pluralistic background of many Europes. 3

\footnotetext{
${ }^{3}$ Tony Judt, Uma Grande Ilusão? - Um ensaio sobre a Europa, p. 66.
} 
Leaving the past aside, we must now look into the future of the idea of Europe. Almost no one would disagree if we say that it is perhaps easier to find stronger ties to a possible European identity in a future of shared causes. And where is the future of the idea of Europe more at stake if not in the dilemmas of the contemporary global environmental crisis and in the transition to sustainability as a paradigm?

But where can we find the sociopolitical agents in order to shape a new cosmopolitan and environmental idea of Europe in the age of the Anthropocene and to implement a model of an enviro-social contract based on hope and utopia? The answer is: we must return to the city (ies).

\section{On the Return to the City as a Possibility of a New Environmental and Cosmopolitan Idea of Europe}

The direction to rethink the idea of Europe through a possible cosmopolitan politics of cities was pointed out by Ulrich Beck in one of his last essays, "Cosmopolitan Communities of Risk: From United Nations to United Cities" (written with Anders Blok), published posthumously in a book called The Metamorphosis of the World (2016).

The main question Beck poses there is this one: can cities, involved in transnational political organizations destined to forge solutions to the global environmental crisis, contribute to rethink the idea of Europe through the creation of a cosmopolitan political culture in face of an idea of Europe plunged in a sociopolitical crossroad?

In the age of the Anthropocene more than half of the world's population lives already in urban spaces. Considering environmental issues, first and foremost climate change, as the main agents of sociopolitical metamorphosis in the Second Modernity, and given the institutional paralysis of the conceptual First Modernity nation state's political culture, Beck displaces his methodological cosmopolitanism thesis from the space of nation state to the political orbit of the cities. 
Unlike nation states, cities, as cosmopolitan communities of global risk and through their historical sociopolitical autonomy, are in a better position to forge a new model of political action to face the global environmental dilemmas of our contemporary world. 4

In a historical moment in which the idea of Europe and its existence are dangerously at stake, we need to reshape it from the core. According to this, we defend the thesis that cities can become an axis for an alternative European sociopolitical paradigm, and also a way to expand conceptually the idea of Europe with a cosmopolitan dimension applied to its future.

But, as we argued in Section 3 regarding the inability of the classical elitist idea of Europe to forge a solid European civil society, the future cosmopolitanism of its idea contains one crucial and particular feature: in order to be fully accomplished, and also to overcome several intellectual constraints pointed in the previous pages, the research of a new environmental and cosmopolitan idea of Europe in the Anthropocene, envisaged through cities and not nation states, presupposes also a strong interdisciplinary dialog with history.

Second Modernity's cosmopolitanism, non-hegemonic and culturally inclusive, opposed to First Modernity's cosmopolitanism, refuses the onedimensionality of both the current European sociopolitical landscape and the idea of Europe. According to this argument, we sustain that to rethink the idea of Europe through a possible cosmopolitan politics of cities in the age of the Anthropocene we need to go beyond Beck's methodological cosmopolitanism as a new sociopolitical culture and to endow it with a solid dimension of historical and cultural cosmopolitanism.

What do we mean by this? We mean that, in order to achieve an effective and culturally inclusive dimension of cosmopolitanism compatible with a pluralistic Second Modernity, we must necessarily establish an interdisciplinary approach with the cultural history of cities that contributed to the genesis of the idea of Europe. In our perspective without a dialogue with its past cosmopolitan roots the concept of cosmopolitanism would remain incomplete.

\footnotetext{
${ }^{4}$ Ulrich Beck, The Metamorphosis of the World, p. 8.
} 
Although due to the still very embryonic phase of our research in the topic of a new cosmopolitan and environmental idea of Europe through cities as possible cosmopolitan agents in the age of the Anthropocene, we cannot go further than this by now.

Therefore, we are forced to finish these pages with a kind of inconclusive conclusion, but pointing clearly the way to the further development of a new idea of Europe: we sustain that the intellectual background of the idea of Europe is not only in debt to Greco-Roman and Judeo-Christian influences.

It is also debtor in pre-modern times to obscured cities such Ptolemaic Alexandria, Sassanid Gundeshapur, Bagdad and Al Andalusian Cordoba and Toledo. These were veritable intellectual and cultural centers, and without the laborious process of translation of works and cultural transmission of knowledge (namely Greek science made from the High Middle Ages on) possibly Europe would not have achieved its universal hegemony since the dawn of Modernity.

\section{References}

Barber, B. (2013). If Mayors Ruled the World. New Haven: Yale University Press.

Beck, U. \& Grande, E. (2007). Cosmopolitan Europe. Cambridge: Polity Press.

Beck, U. (2013). A Europa alemã: De Maquiavel a "Merkievel". Estratégias de poder na crise do euro. Lisboa: Edições 70.

Beck, U. (2016). The Metamorphosis of the World. Cambridge: Polity Press.

Bloch, E. (1995). The Principle of Hope. Cambridge: The MIT Press.

Dobson, A. (2003). Citizenship and the Environment. Oxford: Oxford University Press.

Dobson, A. (2000). Ecological Citizenship: A Disruptive Influence? In Charles Pierson \& Stephen Tormey (eds.), Politics at the Edge: The PSA 
Yearbook 1999 (pp. 1-29). Houndmills, Basingstoke and New York: St. Martin's Press.

Hamilton, C. (2015). Getting the Anthropocene So Wrong. The Anthropocene Review, 2 (2): 1-6.

Jonas, H. (1995). El Principio de Responsabilidad - Ensayo de una ética para la civilización tecnológica. Barcelona: Herder.

Judt, T. (2012). Uma Grande Ilusão? - Um ensaio sobre a Europa. Lisboa: Edições 70.

Rego, B. (2016). O Caos Global da Modernidade - O Século XXI segundo Ulrich Beck. Lisboa: Esfera do Caos.

Rego, B. (2016). Do Contrato Ambio-Social a uma Antropologia da Esperança - Cidadania e Sustentabilidade na Era da Crise Ambiental. Saarbrücken: Novas Edições Académicas - OmniScriptum GmbH \& Co. KG.

Ricoeur, P. (1986). Lectures on Ideology and Utopia. New York: Columbia University Press. 